They make-mistakes, too. Dr. Carstens has seen men tie off a tube containing pus, and the patient has a postoperative exudate. The way to do is to cut the tube in a V-shaped way and then bring the ends of the $\mathrm{V}$ together and cover it all over with peritoneum. Then, as a rule, there will not be any adhesions. To dig through the intestines and try to break up adhesions is bad. If it is in a pus case, Dr. Carstens advised taking a little rubber tube with a cross piece, putting it in the cul-de-sac and draining through the vagina. In the place of peritoneum one can use Cargile membrane. Dr. Carstens has most trouble in cases in which he does conservative operations those in which he leaves half a tube or an ovary, or in which he does an abdominal or vaginal hysterectomy and leaves one ovary. Another thing at fault is the after-treatment of these patients. They do not get enough to drink. One can not get absorption and elimination from solid tissues. These paticnts need liquids, and must be flushed out. The eliminating organs must be opened up. Every patient should receive two or three quarts of saline solution by rectum or under the breast immediately after the operation. They must have plenty of water, at least three quarts a day, one-half pint or a pint at a time, if the stomach is all right. Then, if there is a little exudate, Dr. Carstens uses a mercurial. He commences with protoiodid of mercury, one-eighth of a grain every three hours, until he has given about thirty doses. That acts as an alterative and absorbent and opens up the lymph channels, and the patients get along better. They have comparatively few complications.

Dr. Frank T. Andrews, Chicago, agreed with Dr. Carstens that infection often comes from the cut extremity of the tube, but his method of prevention has been more radical than Dr. Carstens'. He removes the whole tube, even into the horn of the uterus, and then closes the wound with a web stitch, often not ligating the uterine and ovarian arteries, simply running a stitch along the top of the broad ligaments. 'That, however, depends entirely on the individual case.

Dr. H. C. Crowell, Kansas City, said that the worst sequelæ and the most important are those that follow these operations. If it were not for the kindness of Nature in absorbing adhesions, surgeons could not enter the abdominal eavity. However careful the procedure, the endometrium is more or less disturbed and sequelæ result. Dr. Crowell believes that the age of the silk suture has passed, but stated that catgut is a source of trouble if not carefully prepared. The knot in the suture gives rise to an exudate which may end in an abscess. He believes that a shorter-lived catgut may be used safely, because the ligation of vessels requires a very short time for perfect occlusion. The technic is the most important point. Dr. Crowell thinks that patients ought to get up early, as fluids gravitate toward the pelvis if the patient is in the erect position. He advised getting the patient up on the second or third day and encouraging circulation by putting her on her feet and allowing her to walk. Exudates are then. absorbed. He has allowed hysterectomy patients to get up on the second day and always inside of a week. He is satisfied that these patients do better than they would if kept in the recumbent position for a long time.

Dr. W. F. Wakefreld said that the class of cases Dr. Pantzer spoke about are ruled out of the discussion. The paper expressly excludes them. These are mechanical conditions that are practically never found while the patient is in bed, and Dr. Wakefield has examined these patients carefully for the last two or three years. It is after the patients get up that these conditions are found, and even then they depend on how slow convalescence has been. If very slow, exudates are rarely found at all; if rapid, in from two to eight weeks after the patient begins to walk, one finds these tumefactions. Dr. Craig's case illustrates exactly the class of cases referred to. Dr. Wakefield said that he could have mentioned from fifteen to twenty similar cases. Gynecologists have not been looking for these indurations and, therefore, they have not found them as often as they have been present. These,tumors are pure mechanical entities. Just what the mechanism is he is not prepared to say. Sepsis has nothing to do with it. $\mathrm{He}$ has never found sepsis in any case. An embarrassed circulation is probably the Iargest factor, and this circulatory irritation acting on the new tissue accounts for the condition in all likelihood. He has never cut into one of these tumors, and he believes that if he had he would not have found anything. Nevertheless, unless the absorption of this mechanical mass is brought about, the patients will suffer from ill-defined pelvic irritation, almost as troublesome as the original condition for which they were operated on. Dr. Wakefield explained that he used the term exudate because it is the term used in the literature. It refers to any tumefaction about the field of operation. He thinks it is a misnomer. Throughout his paper he speaks chiefly of the so-called exudates and calls them mechanical tumefactions. He does not believe that they are real exudates. The percentage of their occurrence depends not so much on the technic of the operator as on other things. ILe removes tubes just as Dr. Carstens does. When he men. tioned 60 per cent. he did not mean that there was a definite tumor in that percentage of cases, but that on examining these women in from six to eight weeks after operation he has found in 60 per cent. either a thickening of the broad ligament or a distinct tumefaction. He does not believe in letting patients get up early. In carrying on a series of experiments on patients he found that these tumefactions are almost invariably produced in patients who get up early. The longer the patient can be kept in bed and the more protracted the convalesrence the less likelihood there is for the formation of these timmefactions.

\section{HERNIA OF THE TUBE WITHOUT THE OVARY.*}

\section{FRANIK T. ANDREWS, M.D.} CIIICAGO.

I wish to report four cases of hernia of the tube without the ovary, one furnished by Dr. James $H$. Haberlin, Pawtucket, R. I., and another by Dr. H. H. Judd, Chicago, the third and fourth being from my own practice.

I have made an exhaustive search for recorded cases of hernia of the female pelvic organs and find 362 cases sufficiently well reported to be of value. These cases, with my own, may be tabulated thus:

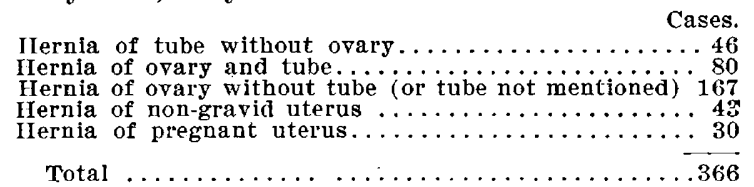

Early in the second century, Soranus of Ephesus described the first case of hernia of the ovary. No further observation was made until 1\%16, when Louis Leger de Gouey of Rouen wrote an article citing a case of intrahernial tubal pregnancy.

The literature of tubal hernia is practically the same as that of ovarian hernia, but in 1893 Lejars $^{1}$ published an article on hernia of the Fallopian tube without the ovary; and in 1901 Dr. Paul F. Morf ${ }^{2}$ published a very complete work on the same subject, reporting 24 cases, including his own.

\section{REPORTS OF FOUR CASES.}

I wish to record here the following cases:

CASE 1 (Reported to me by Dr. T. H. Judd).-Patient, a Swedish widow, 56 years of age, and admitted to Cook County Hospital May 12, 1905. First noticed small tumor in left groin fourteen years ago after doing some heavy lifting while eight months pregnant. Tumor was easily reduced, and gave no trouble until one and one-half vears ago, when it again appeared and reduction was impossible. Physician was called

- Read in the Section on Obstetrics and Diseases of Women of the American Medical Association, at the Fifty-sixth Annual Ses slon, Julv, 1905.

1. Revue de Chirurgie, January and February, 1893.

2. Annals of Surgery, 1901 . 
who obtained reduction. This attack was accompanied by considerable pain at site of tumor, restlessness, irritability and vomiting. Had similar attacks one year ago, also three months ago. Present attack is accompanied by more pain than before, and patient lad romited several times on day of admittance.

Examination showed sinall irreducible tumor in left inguinal region, firm in consistency, except at distal extremity, where it was tympanitic. Tumor gave slight impulse on hard coughing and was somewhat tender.

Operation performed by Dr. Kahlke. Incision over tumor, sac opened and dissected loose. Sac contained portion of ileum, which was rery dark colored, a portion of broad liagment and a loop of Fallopian tube while ovary was situated within abdominal cavity, but firmly pressed against femoral ring and neck of sac. Tube and ovary replaced, sac excised and wound closed with catgut. Chart of temperature, etc., was as follows:

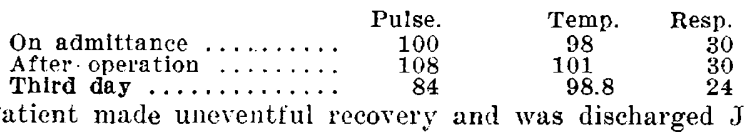

Patient made uneventful recovery and was discharged June 13 , 1905 .

Case 2 (Reported to me by Mr. J. H. Haberlin).-Mrs. B. N., 45, white, United States.

Family History.-Father died at 58 years of pulmonary tuberculosis after four years' illness. Brother, third born, died at 23 of pulmonary tuberculosis, two years' illness. Brother, second born, died at 35 years of Landry's paralysis. Brother, fifth born, died at 39 years of chronic nephritis and hepatitis (alcoholic etiology). Mother living and well at 76 years, excepting slight edema of legs and periodic subacute rheumatic attacks. Yiclds readily to treatment. Brother, 50 years, in good health. No one beside the patient ever had a hernia.

Prcvious History.--Patient was a full term child, born in normal labor. Never sick in infancy. Breast fed until late in infancy. Had measles and pneumonia in early childhood. Otherwise well. Jumped from a high wall at 7 years of age and received hernia in the left groin. Twelve years ago, while lifting heavy weight, received hernia in right groin. Was treated by Dr. O. Edwards ${ }_{2}$ Boston. He injected a solution that caused intense inflammation, with consequent great suffering. After a week, the symptoms of inflammation subsided and patient was discharged cured. The left hernia never recurred, but the patient thought she felt the right hernia recurring and dropping lower down. The doctor, when again consulted, however, insisted that the hernia was cured and refused further procedures. Every since this time, patient has had a hernia in the right groin.

Personal History.-Patient uses alcohol moderately. Has worked in a department store as clerk since husband's death (fifteen years ago) until about two years ago. Appetite good. Bowels alightly constipated Sleeps well. Disposition cheerful. Menses appeared at 16 years; were then regular, flowed six to seven days without pain until 19 years of age. Then patient suffered pain during the flow. Married at 20 years. $\mathrm{Had}$ child at 21 years and at 25 years. Labor normal. Never miscarried. Has had leucorrhea ever since marriage almost constantly, but amount and character has varied. Sometimes discharge was thick, white and tenacious, sometimes it was thin and white or vellow. Widow for fifteen years.

Present Illness.-I was called to see the patient May 14, 1905 , at $8: 30$ p. m. Found her seated in a rocking chair, tearful and evidently suffering great pain. (Patient usually a stoic.) Hernia has been down four days and patient is unable to reduce it. Usually she can reduce it at its worst stage by lying on the floor and putting feet on the bed and then gently maniplating the tumor. Patient has not menstruated for six weeks. Never before has this latter occurred except in pregnancy.

Examination.-Firm rounded tumor as large as grape fruit. Patient placed in dorsal decubitus with feet raised, and 1 manipulated the hernia to obtain reduction. Manipulation caused great pain if done at all but gently. Tumor gradually reduced to size of small lemon, when further reduction was absolutely inpossible.

Diagnosis.-Ruled out tuberculous femoral glands, hernia of tube and ovary and enterocele in favor of incarcerated epiplocele (inguinal).

Operation.-This was advised as only resort. Patient consented. Patient was removed to St. Joseph's Hospital, Providence, R. I. Dr. William L. HIarris of the surgical staff agreed that it was epiplocele, but thought it femoral and strangulated. In discussion, he did not insist on the latter condition, however. Operation was by Dr. Harris. Incision parallel to Poupart's ligament. Sac exposed and seen to contain a light yellow-colored serum. Tumor as large as small lemon, as before mentioned. Tumor punctured and serum allowed to escape. Sac (peritoneal) incised and the cyst wall seen to be connected to one of the fimbrix of the tube, all of which were in the wound. Fimbriated end of the tube amputated. Hernia was femoral.

Postoperative History.-Ideal patient; ideal result. Left the hospital fifteen days after operation. Was obliged to use napkins every day in the hospital for slight saneous discharge. Pain in wound week after operation disappeared in three days. Menses appeared two weeks after return home; lasted scarcely five days, with decidedly less pain and discomfort than usual.

CASE 3 (author's).-March 24, 1904, I operated for Dr. Childs of Roseland, Ill., on Mrs. K. (multipara, aged 32, married eleven years), for diseased appendages. 'There was a history of gonorrheal infection three years previous, followed by salpingitis. A right inguinal hernia, caused by carrying pails of water, had existed for sixteen years. Operation disclosed the usual condition of adhesion on both sides, except that the right tube led in a straight line to the hernia. About one-half the tube was adherent, together with omentum in the hernial sac. The internal inguinal ring was patulous, a Inop of bowel evidently slipping in and out of the sac readily. I removed the appendages and repaired the hernia. The patient made a normal recovery.

CASE 4 (author's).-Mrs. W., aged 23; admitted to Mercy Hospital April 30, 1905. Married one and one-half years. Had a child born March 2, 1905.

Previous History. - No tuberculosis in family. Had as dis eases of childhood measles, whooping cough and scarlet fever. Suffered occasionally from pain in abdomen and diarrhea. Periods began at age 13 , and were regular every four weeks. Flow profuse and not very painful. Never had any weakness or pain in the right groin nor knew of any tumor or hernia. After birth of a child, March 2, 1905, she evidently suffered from infection, giving a history of irregular chills, alternating with high fever. At first there was considerable vomiting. Since then there has been great pain and tenderness in the right inguinal region, with the gradual development of great swelling.

Examination.-Temperature 101 to 103 ; pulse 100 to 140 . The abdominal wall on the right side was swollen and edema. tous, the swelling extending upward to the ribs and downward on to the anterior surface of the thigh. Digital examination revealed a mass involving the right appendages, but nearly filling the pelvis. The outlines of ovary, tube or uterus could not be distinguished.

Diagnosis.-Pelvic abscess due to rupture of right pyosalpinx with adhesions to anterior abdominal wall.

Operation.-I was assisted in the operation by Drs. Barnes and Norris. Fther was given by Dr. Mitchell. Usual preparation. Trendelenburg position. Incision 4 inches long in median line. Pelvic organs on right side were matted to gether and covered by adherent omentum and intestine. After separating the omentum and bowel from the mass, the uterus could be seen drawn to the right. Laparotomy sponges were inserted to wall of the field of operation. On separating some uterine adhesions with the finger and drawing the uterus to the Ieft, it was discovered that the right tube and round ligament had been serered at the uterine horn. On introduc. ing a retractor to lift the abdominal wall, pus could be seen escaping from the internal inguinal ring into the peritoneal cavity. The parts were cleansed of pus, and the finger inserted through the ring into the cavity of the abscess. An incision was made through the skin into the hernial abscess and a gauze drain inserted. A gauze drain was also used in 
the median incision and the remainder of the wound closed by silk-worm gut, interrupted sutures. The patient made an uninterrupted recovery and left the hospital May 30.

The following cases I have gleaned from the world's literature:

AUBRY : ${ }^{3}$ Age 70 , postmortem examination revealed hernia of the Fallopian tube. 'Tube had passed through femoral ring and lay in front of the pectineus muscle, between the adductors and the femoral vessels.

BERARD : 4 Age 45, acquired crural hernia of the right tube; irreducible. Exploratory puncture evacuated clear fluid; patient showed symptoms of a phlegmon and death occurred seven days after evacuation. At autopsy, a seropurulent peritonitis was found. The neck of the sac passed through the crural ring, and within it the Fallopian tube, somewhat enlarged. No other viscera were found in hernial sac.

Boudrs : $\mathbf{5}$ Age 50, acquired crural hernia : irreducible. Operation, sac was found to contain the Fallopian tube alone, strangulated by neck of sac. Recovery.

BRUNner: Case 1.-Age 68, irreduclble; acquired crural hernia. Operation; the sac being opened, clear fluid escaped, disclosing swollen and edematous extremity of right Fallopian tube; the tube
was reduced; a lipoma situated in upper portion of sac was isolated and extirpated. Recovery.

Case $2^{6}$.-Age 38 , acquired inguinal hernfa; Irreducible. Operation; clear fiuld tinged with red escaped from sac after incision. Right Falloplan tube was contained in sac. by making traction on tube, the ovary was dragged forward, but was found to be perfectly healthy. Tube was reduced and the sac ligated and resected. Recovery.

ChIENE: $:^{T}$ While dissecting the body of a woman, aged 73 , found an obturator hernia; the sac contained two-thirds of the Fallopian tube and two inches of the lleum. The bowel was gangrenous and had given away. On the opposite side were two obturator herniæ, an anterior sac formed of parietal peritoneum and the posterior sac containing the outer half of the Fallopian tube. A year prevlous she had been successfully operated on for strangulated fe. moral hernia.

DEmodis : $:^{3}$ Operated in a case of hernia of the tube, where there was adherence to the sac; traction brought the ovary to riew.

Deaver, J. B. : ${ }^{9}$ Strangulation of the fimbriated extremity of a Fallopian tube of the right side, which was thought to be a femoral hernia.

DOLBEAU : ${ }^{10}$ Tumor in inguinal region presenting signs of an abscess of inguinal canal. Incision pus escaped. Peritonitis and death. Autopsy showed pus collection surrounded by hernia sac. whlch contalned likewise a serous cyst. Incision of cyst revealed Falioplan tube.

DUPONT:11 Age 38, in fifth month of pregnancy, acquired inguinal hernia. Exploratory puncture caused escape of yellowish fluid. Operation revealed herniated Fallopian tube, organ was reduced. Reovery

Erichsen :12 Age 37 , acquired left strangulated hernia. Operation sac contained clear flutd and the swollen fimbriated extremity
of the Fallopian tube which was tightly nipped at the neck of the sac. Tube was returned into abdomen. Recovery.

FEne $:^{13}$ Child, age 3 weeks; at autopsy a hernial sac containing exclusively the fimbriated extremity of the Fallopian tube was dis. covered external to the round ligament. It was easily reduced, but returned immediately after pressure was removed.

DEFrancisco: $1^{14}$ Age 32 , acquired inguinal hernia of the left DEFrancisco:
tube, irreducible. Ope 32 , acquired inguinal hernia of the left
operation; sac exposed and opened. Contained adherent tube; the latter was separated as much as possible; sac was separated from surrounding parts and closed with sutures and was separated from surroundin
stumps replaced. Recovery.

FRANK : ${ }^{16}$ Age 21, left tubal hernia, acquired. Operation; removal of tube and sac; recovery. Had been operated on when a child for hernia on same side. No trace of ovary could be found in last operation.

GOEPEL :10 Age 62, acquired right crural hernia, irreducible. Celiotomy; sac contained serous fuid and dilated Fallopian tube; it was removed, as was likewise the corresponding ovary, which was sclerotic. Recovery.

DD GoukY ${ }^{17}$ (of Rouen, in 1706): Young woman, hernial sac of right groin; when sac was opened, clear fluid escaped. (On reading original, this is seen to be evidently hernia of tube.) Inside another bag a live fetus, 6 inches long, was found; latter was removed, tying the cord. Placenta likewlse came away; it was moved, tying the cord. Placenta likewlse came away

LEJARS : ${ }^{18}$ Age 39 , acquired inguinal hernia of the right tube; strangulation. Operation; sac contained blood-stained fluid and Falloptan tube; tube was excised with sac: it was gangrenous in places. A portion of the wall of the urinary bladder also became herniated through the internal ring in company with the hernial sac. Recovery.

3. Bull, de la Soc. Anat. de Par., 1842, p. 143

4. L'Experience, 1839 , p. 216

5. Lyon Medical, 1899 , vol. xcl, p. 231.

6. Beit. z. kltn. Chir., vol. iv, 1889 , p. 32.

7. Ed. Med. Jour., January, 1871 , p. 601.

8. Annales de Gynec,, 1900 , vol. liiit, p. 203.

9. Annais of Surgery, 1904, vol. xl, p. 154 .

10. Sociéte Anatomique, 1854 , p. 72.

11. Bull. de la Soc. med. de la Sulsse romande, 1878, p. 115

12. Science and Art of Surgery, vol. ii, Tenth Edition, p. 1297
13. Rev. mens. de Med. et de Chir., 1878, vol. ili, p. 479.

13. Rev. mens. de Med. et de Chlr., 1878 , vol.
14. Beit. z. kiln. Chir., 1900, vol. xxiil, No. 2 .

15. Internat. klin. Rundschau, Wien, 1892, vol. vi, p. 1098

16. Berichte der med. Gesellschaft, zu leipzig, March, 1896.

17. La veritable Chir. etab. s. l'experience et la raison, Roan,

1716,5 partie, p. 401.

18. Revue de Chirurgie, 1893, vol. x111, p. 13.
LENT : 10 Age 52, acquired crural hernia of the left Fallopian tube ; dropsy of the bernial sac. On dissection, bloody fluid was sac. Recovery.

IATAGiter:20 Age 19 months; since the age of 6 months right inguinal helnia. Operation: sac, formed by the canal of Nuck contained a knuckle of the right Fallopian tube. Exclsion, followed by recovery.

Kousmine: 11 Age 36 ; left acquired inguinal hernia; irreducible Operation; after opening sac, large quantlty of seropurulent fluid escaped. This disclosed a cystic Fallopian tube, the external half of the tube only occupying the sac. Recovery.

MaYdL :22 Age 47; acquired femoral hernia; irreductble. Opera. tlon; after incision, escape of hemorrhagic fluid, which disclosed knuckle of Fallopian tube in the femoral canal; the uterine half of the tube was converted into a cyst; the strangulated portion of the tube consisted of a loop, which had passed back into the abdominal cavity after having passed out through crural ring. He extirpated the sac containing the tube; also removed the correponding ovary. Recovery.

Moller : ${ }^{23}$ Age 46 ; right inguinal hernia, acquired. Herniotomy ; sac was found to contain a pyosalpinx. On account of collapse peration was hastily ended. Recovery with a formation of a istula.

Monf :24 Age 24; left congenital inguinal hernia of the Fallopian tube; irreducible. Operation; sac was removed with its contents, together with left ovary; sac contained omentum, into which mass the tube was traced, its fimbriated extremity being completely surrounded by omental tissue; from it the infundibulo

could be traced; passing out of sac. Recovery.

MorTon AND Failopian tube and its fimbriated extremity. Reduced sac ligatured ond cut away. Recovery.

Case 2.26-Age not known; strangulated right femoral heria. Herniotomy; sac contained gangrenous omentum and gangrenous ruptured bowel and end of right Fallopian tube, which 列 from shock twelve hours later. Autopsy.

NelatoN:20 Child died twenty-four hours after birth; right in gulnal hernia containing Fallopian tube.

PicQub AND Polrier :27 Age 78 ; acquired obturator hernia ; strangulation; death. Autopsy, sac formed by peritoneum contained a knuckle of

igament. (Bilton) 28 Age 37 ; acquired strangulated femoral her POLLARD (Bllton) : ${ }^{2}$ Age 37 ; acquired strangulated extremity of the left Fallopian tube, which was tightly nipped at the the neck of the sac. The constriction

urned into the abdomen. Recovery. SALNELLE: ${ }^{29}$ Age 19 days; congenital hernia on the right side the right Fallopian tube, red and swollen. Death.

SCHOLLER : ${ }^{\circ}$ Age 20 days; congenital inguinal hernia; convulslons and death. Autopsy. showed hernia of the right tube. It was red and swollen; the round ligament was a little shorter than that on the other side and the uterus slightly displaced.

of VAUCHER : 31 Age 23 ; probably congenital ingulnal bernia: irreducible. Operation; sac contalned left Fallopian tube without ovary; sac and tube excised. Recovery.

VoG 32 a 38 ; acquired inguinal hernia; irreducible. Operation; opening of the sac; escape of blood-stained fluid, disclosing ront fallopian tube in bottom of sac. The tube was returned into right fiallopian tube in bottom or sac. The tube

bominal cavity; the sac removed. ingutnal hernia; irreducible. welling "opened," discharged a serous fetid pus, after which patent's opened, discharged improved. The next day a small black tlent's general condition improved. The next day a small black, gangrenous body was found in the

as the Falloptan tube. Recovery.

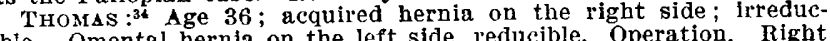
ible. Omental hernia on the left side, reducible. Operation. Right crural hernial sae contained the fimbriated extremity of the Falloplan tube. Gimbernat's ligame

Ty after last pregnancy : symptoms of strangulation. Operation; sac after ined the right tube. resection of the tube above the strangu contalned the ricil cure. Recovery.

VASSAL : so Reports another obselvation by Broca. Child, age 14 montbs; congenital inguinal hernla; strangulated for twentyfour houls. Herniotomy, the tube was found in the sac. Temperature after operation $37.4 \mathrm{C}$.: the following days, 37 . Recovery.

WALDEY : 37 Demonstrated before the Obstetric and Gynecologic soclety of Berlin, June, 1896, an inguinal hernia, in which lay a tube. IVALTER $^{38}$ Aged 14 months; at 6 weeks of age tumor was frst

19. Gazette Med. de Strasbourg, 1881, No. 9, p. 97.

20. Schultz: Thèse de Paris, 1898 .

21. Revue de Chirurgie, April, 1895, p. 313

22. Wien. Klin. Rundschau, 1895 , vol, ix, p. 17.

23. Hyglea, 1894, No. 5 , p. 431 .

24. Annals of Surgery, 1901, ,ol, xxxiil, p. 247.

25. London Lancet, Feb. 17, 1894, p. 403 .

26. Elements de path. chir., 1857, vol. iv, p. 440

27. Revue de Chtrurgie, 1892 , vol. xii, p. 33

28. Ertchsen: Science and Art of Surgery, vol. ii, p. 1297

29. Thèse de Paris, 1880 , p. 84.

31. Thèse pour la doctorat, 1854 , p. 45

32. Centralbl. für Gynäk., 1886, vol. $x$, p. 166

33. Hufeland: Jour. der pract. Heilkundl., 1809 , No. 3, p. 139.

34. Brit. Med. Journ., 1896, vol, xl.

35. La Clinica Moderna, 1904, No. 22 .

36. Thèse de Paris, 1895.

37. Centralbl. f, Gynäk., 1896, vol, xx, p. 792

38. Schultz: Thèse de Paris, 1895 . 
observed in inguinal region. Operation; the hernia contained a loop of small intestine and the Fallopian tube strangulated mod-

erateiy. Reduction. Recovery.
WALTHER (G. Th.) : $:^{a s}$ Age - right inguinal hernia. Operation; ac was found to contain a cystic dilated accessory. Falloplan tube (congenital malformation).

WALTHER (G. Th.) :39 Age - ; right inguinal hernia, Operation; displaced to the right. The right tube and corresponding tuboovarian ligament extended into right inguinal ring. On left side, internal inguinal ring was occluded by fimbriated extremity of the left tube passing into it.

Case 2.41 Age 6 months; congenital inguinal hernia of the left tube found; postmortem the sac contained the tube only. The left ovary was situated in the internal iliac fossa on the right side; tube and ovary occupied their normal position. Uterus was displaced to the left.

WXETH :22 Age 38 ; strangulated right inguinal hernia; when sac was opened congested Fallopian tube was found; pus and feces welled up from the abdominal cavity through the neck of the small loop of intestine was found gangrenous, ruptured; death six bours after operation.

SUMMARY OF ABONE CASES OF HERTIA OF THE TUBE WITHOUT HERNIA

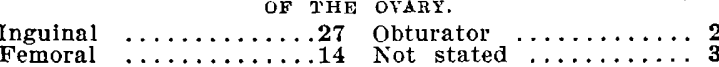

Table 1. - Inguinal Hernia.

\begin{tabular}{|c|c|c|c|c|c|c|}
\hline & 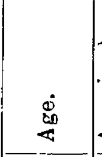 & 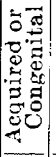 & $\overbrace{0}^{\circ}$ & Operatiion. & 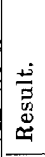 & Contents of Sac. \\
\hline drews, 1 . & 32 & $A$ & $\bar{R}$ & Retu & $R$ & Tube. \\
\hline s, $2 \ldots$ & $\begin{array}{l}23 \\
38\end{array}$ & A & $\begin{array}{l}\mathbf{R} \\
\mathbf{R}\end{array}$ & $\begin{array}{l}\text { d b b } \\
\text { tion. }\end{array}$ & $\begin{array}{l}R \\
k\end{array}$ & $\begin{array}{l}\text { Pyosalpinx. } \\
\text { Tube and clear flu } \\
\text { tinged with red. }\end{array}$ \\
\hline Dolbeau.. & $\cdots$ & & & of $\mathrm{ab}$. & D & Postmortem showe \\
\hline Dupont ... . & 38 & $A$ & & Ret & $\mathbf{R}$ & Tube and clear fluir \\
\hline éré. Francisco. & $\mid \begin{array}{c}3 \text { weeks } \\
32\end{array}$ & $\begin{array}{l}\mathrm{C} \\
\mathrm{A}\end{array}$ & L & $\begin{array}{l}\text { op } \\
\text { Post } \\
\text { Retp } \\
\text { op }\end{array}$ & $R$ & $\begin{array}{l}\text { Tube. } \\
\text { Tube. }\end{array}$ \\
\hline de Goney.. & $\underset{\text { lady }}{\text { Young }}$ & $\ldots$ & $\mathrm{R}$ & $\begin{array}{l}\text { Removal of } \\
\text { extrauterine. } \\
\text { fetus. }\end{array}$ & & $\begin{array}{l}\text { Pregnant tube sur } \\
\text { rounded by cleat } \\
\text { fuid. }\end{array}$ \\
\hline Jalaguier. & $19 \mathrm{mo} .$. & $\mathrm{C}$ & $\mathbf{R}$ & Excis & $\mathbf{R}$ & $\begin{array}{l}\text { le of tube } \\
\text { lof Nuck. }\end{array}$ \\
\hline Kousmin & 36 & A & $\mathbf{L}$ & Excision. & $\mathbf{R}$ & Cys \\
\hline ejars. & 39 & A & $\mathbf{R}$ & Excision. & $\mathbf{R}$ & 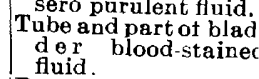 \\
\hline $\begin{array}{l}\text { Möller. . . . } \\
\text { Morf... . . : } \\
\text { Morton a n } \mathrm{d} \\
\text { Butler. }\end{array}$ & $\begin{array}{l}46 \\
24 \\
41\end{array}$ & \begin{tabular}{l|}
$\mathrm{A}$ \\
$\mathrm{C}$ \\
$\mathrm{A}$
\end{tabular} & $\begin{array}{l}\mathrm{R} \\
\mathrm{L} \\
\mathrm{R}\end{array}$ & a & $\begin{array}{l}\mathrm{R} \\
\mathrm{R} \\
\mathrm{R}\end{array}$ & $\begin{array}{l}\text { Pyosalpinx. } \\
\text { Tube and omentum. } \\
\text { Tube. }\end{array}$ \\
\hline $\begin{array}{l}\text { Nelaton .... } \\
\text { Salnelle. . : } \\
\text { Scholler. . : } \\
\text { Vassel. . . } \\
\text { de Vaucher.. : } \\
\text { Vogel.. ... }\end{array}$ & $\mid \begin{array}{l}1 \text { day. } \\
19 \text { day: } \\
20 \text { days } \\
14 \text { mo.. } \\
23 \\
28\end{array}$ & $\mid \begin{array}{l}\mathrm{C} \\
\mathrm{C} \\
\mathrm{C} \\
\mathrm{C} \\
\mathrm{C} \\
\mathrm{A}\end{array}$ & $\begin{array}{l}\mathbf{R} \\
\mathbf{R} \\
\mathbf{R} \\
\mathbf{L} \\
\mathbf{R}\end{array}$ & $\begin{array}{l}\text { Postmortem. . } \\
\text { Operation... } \\
\text { Postmortem. . } \\
\text { Operation.. } \\
\text { Excision. } \\
\text { Returned b y }\end{array}$ & $\begin{array}{l}\mathrm{D} \\
\mathrm{R} \\
\mathrm{R} \\
\mathrm{R}\end{array}$ & $\begin{array}{l}\text { Tube. } \\
\text { Tube, strangulated. } \\
\text { Tube red and swolle } \\
\text { Tube, strangulated. } \\
\text { Tube. } \\
\text { Tube and bloody fluid }\end{array}$ \\
\hline Voight & 36 & $A$ & $\mathbf{R}$ & Incised .... & $\mathbf{R}$ & $\mathrm{Cu}$ \\
\hline & is mo. & $\mathrm{C}$ & & b y & $\stackrel{?}{R}$ & \\
\hline Walther. & ? & $\mathrm{C}$ & $\mathrm{R}$ & Operatic & $?$ & ated, acc \\
\hline viart, 1. & $2 \mathrm{mo} .$. & C & D & Postmortem. . & & ne in $e$ \\
\hline iart. $2 .$. & $6 \underset{38}{6}$ & C & $\begin{array}{l}\mathrm{L} \\
\mathbf{R}\end{array}$ & $\begin{array}{l}\text { Postmortem . } \\
\text { Excision . . }\end{array}$ & $D^{\circ}$ & $\begin{array}{l}\text { Tube. } \\
\text { Tube, gangrenous in } \\
\text { testine. Pus a nd } \\
\text { feces walled up. }\end{array}$ \\
\hline
\end{tabular}

ANALYSIS OF TARLE OF INGUINAL HEINIA.

Acquired $\ldots \ldots \ldots \ldots \ldots 11$ Right $\ldots \ldots \ldots \ldots \ldots \ldots$

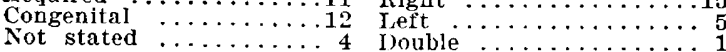
Total $\ldots \ldots \ldots \ldots \ldots, \overline{27}$ Not stated $\ldots \ldots \ldots \ldots \ldots$ Total $\ldots \ldots \ldots \ldots \ldots . .27$

Found postmortem (all infants) $\ldots \ldots \ldots \ldots \ldots \ldots \ldots$

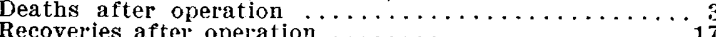
Recoveries after operation $\ldots \ldots \ldots \ldots \ldots \ldots \ldots \ldots \ldots \ldots$ Total ..................... VISCERA CONTAISED IN SAC.

Tube and part of bladder $\ldots \ldots \ldots \ldots \ldots \ldots \ldots \ldots \ldots$

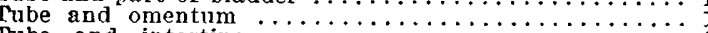

Tube alone intestine $\ldots \ldots \ldots \ldots \ldots \ldots \ldots \ldots \ldots \ldots, \ldots \ldots \ldots, 23$

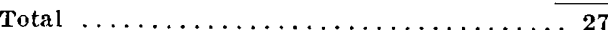

In eleven cases the sac contained fluid.

Clear fluid $\ldots \ldots \ldots \ldots \ldots \ldots \ldots \ldots \ldots \ldots \ldots \ldots \ldots$

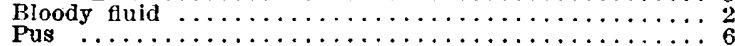

The ages range from birth to 46 years.

39. Centraibl. f. Chlr., 1897, vol. xxiv, p. 771

40. Bull. de la Soc. Anat., July, 1898, vol. Ixxlii, p. 537 .
Table 2.-Femoral hernia.

\begin{tabular}{|c|c|c|c|c|c|c|}
\hline & 实 & 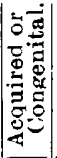 & 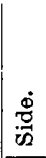 & Operation. & 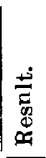 & Contents of Sac. \\
\hline $\begin{array}{l}\text { Andrews, } 1 . . . \\
\text { (Judd's case.) }\end{array}$ & 56 & $A$ & $L$ & $\mid \begin{array}{c}\text { Returned by } \\
\text { operation. }\end{array}$ & $\bar{R}$ & T ube, strangulated; \\
\hline Andrews, 2 (Haberlin's & $4 \bar{s}$ & C & $R$ & Excision. & $\mathrm{R}$ & $\begin{array}{l}\text { Tube, epiploon and } \\
\text { serous fluid. }\end{array}$ \\
\hline $\begin{array}{l}\text { Aubry......... } \\
\text { Berard... }\end{array}$ & .70 & $\stackrel{q}{A}$ & $\stackrel{?}{\mathrm{R}}$ & $\begin{array}{l}\text { Postmortem. } \\
\text { Puncture... }\end{array}$ & $\mathrm{D}$ & Tube. Tube and clear fluid \\
\hline$\underset{\text { Brunner.... . . }}{\text { Boudin... }}$ & $\begin{array}{l}50 \\
63\end{array}$ & A & $\mathrm{R}$ & $\begin{array}{l}\text { Operation. } \\
\begin{array}{c}\text { Returned b } \\
\text { operation. }\end{array}\end{array}$ & $R$ & $\begin{array}{l}\text { Tound postmortem. } \\
\text { Tube, clear fluid and } \\
\text { a lipoma. }\end{array}$ \\
\hline $\begin{array}{l}\text { Deaver... } \\
\text { Goepel... } \\
\text { Lentz... } \\
\text { Maydl... }\end{array}$ & $\begin{array}{l}? \\
62 \\
52 \\
47\end{array}$ & $\begin{array}{l}\stackrel{?}{A} \\
\text { A } \\
\text { A }\end{array}$ & $\begin{array}{l}\mathrm{R} \\
\mathrm{R} \\
\mathrm{L}\end{array}$ & $\begin{array}{l}\text { operation. } \\
\text { Excision } \\
\text { Excision } \\
\text { Excision }\end{array} \cdots$ & $\begin{array}{l}\stackrel{?}{R} \\
R \\
R \\
R\end{array}$ & $\begin{array}{l}\text { Tube. } \\
\text { Tube and serous fluid. } \\
\text { Tube and bioody fluid. } \\
\text { Knuckle of tube and }\end{array}$ \\
\hline$\underset{\text { Butler. }}{\text { Morton }}$ & $?$ & ? & $\mathbf{R}$ & Excision. . . & D & 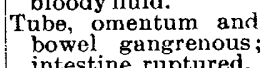 \\
\hline Pollard... . . & 37 & A & $\mathrm{L}$ & Returned by & $R$ & $\begin{array}{l}\text { 1ntestine rupturea. } \\
\text { Tube and clear fluid. }\end{array}$ \\
\hline Thomas.. & 36 & $\mathbf{A}$ & R & $\begin{array}{l}\text { operation } \\
\text { Returned in } y\end{array}$ & $R$ & an omental hernia) \\
\hline Trinci.. & 47 & $A$ & $\mathrm{R}$ & $\begin{array}{c}\text { operation. } \\
\text { Excision... }\end{array}$ & $\mathbf{R}$ & Tube, strangulated. \\
\hline
\end{tabular}

AXALYSIS OF TABLE OF FEMORAL HERNiA.

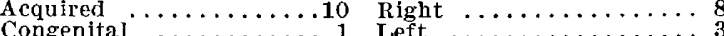

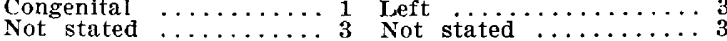

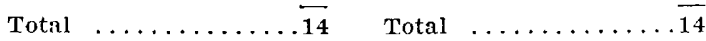

Found postmorten $\ldots \ldots \ldots \ldots \ldots \ldots \ldots \ldots \ldots$ l

Death after operation $\ldots \ldots \ldots \ldots \ldots \ldots \ldots \ldots \ldots \ldots, 2$

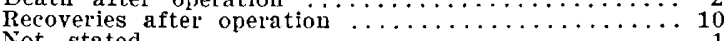

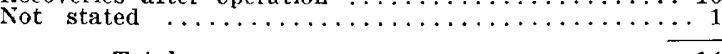

Total $\ldots \ldots \ldots \ldots \ldots \ldots \ldots \ldots$

VISCERA CONTAINED IN SAC.

Tube and part of bladder $\ldots \ldots \ldots \ldots \ldots \ldots \ldots$.

Tube intestine and part of broad ligament................

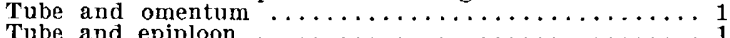

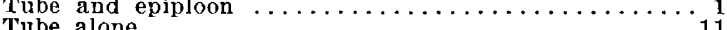

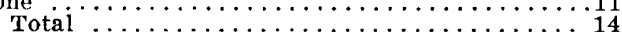

In Brunner's case there was, beside the tube, a lipoma in the sac. in seven cases the sac contained fiuid.

Clear fluid $\ldots \ldots \ldots \ldots \ldots \ldots \ldots \ldots \ldots \ldots \ldots \ldots \ldots$

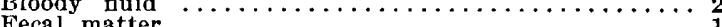

The ages range from 36 to 70 years.

Table 3.-Obterator Hernia.

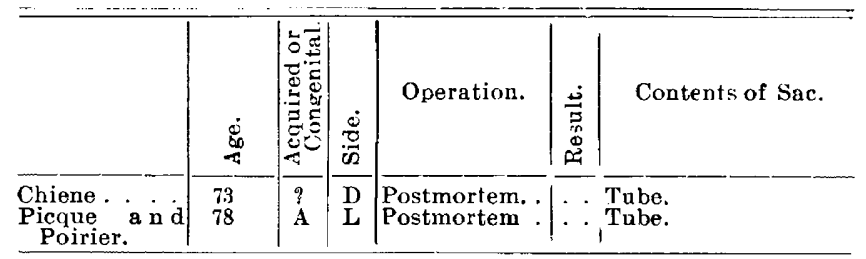

Table 4,- Kind of Hernia Not Stated.

\begin{tabular}{|c|c|c|c|c|c|c|}
\hline ㅇ & 要 & 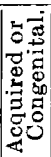 & 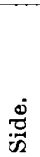 & Operation. & 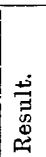 & Contents of Sac. \\
\hline $\begin{array}{l}\text { Demoulin. } . \\
\text { Erichsen } .\end{array}$ & $\begin{array}{l}\frac{?}{37} \\
37\end{array}$ & A & L & Operation. & $\overline{\stackrel{?}{R}}$ & Tube. \\
\hline Frauk. . . . & 21 & $\mathbf{A}$ & $\mathrm{L}$ & Excision. & $R$ & Tube. \\
\hline
\end{tabular}

As hernia of the Fallopian tube, without the ovary, constitutes less than 10 per cent. of the recorded cases of hernia of the pelvic organs, it is evident that a description of the anatomy and the etiology may be best considered in a future paper dealing with the greater subject. Pathologic conditions within the tube may also be better discussed then.

The diagnosis, before the opening of the sac, has not been made, but, perhaps, in the case of a small painless hernia the tilting of the uterus toward the hernia might be sufficient evidence that the sac held only the tube.

41. Annales de Gynec., 1900, vol. liil, p. 202

42. Annals of Surgery, 1894, vol. xix, p. 6 . 


\section{DISCUSSION.}

DR. T. B. EAsTMAN, Indianapolis, said that a woman was referred to him with what had been diagnosed as a labial ab. scess on the right side. It had been incised several times, but the discharge continued. Dr. Eastman made a free incision and after a rather difficult dissection he came on a badly in. flamed appendix which was open at the end and discharging pus. Of course this was responsible for the patient's condition. Dr. Eastman removed the appendix and the patient made a good recovery.

1)R. A. Goldspons, Chicago, stated that a number of years ago a woman of at least 60 years of age came under his care as a hospital patient. She had always been fairly healthy, and she had a femoral hernia of small dimensions that had not given her much trouble. It became irreducible, however, and oceasioned more or less pain, and she had had something of a convulsion, as her illiterate relatives described it. Exam. ination showed a small tumor in the region of the left femoral ring, corresponding to a femoral hernia, that was not reducible by ordinary taxis. On opening the sac the ovary became apparent; it was adherent, with a small amount of omentum. The operation presented no difficulty and the patient made a good recovery.

\section{SOME COMPLICA'TIONS OF PREGNANCY. TREATED SURGICALLY.* FRANCIS D. DONOGHUE, M.D. BOSTON.}

Within comparatively few years, our knowledge of appendicitis and neoplasms, complicating pregnancy, has been considerably increased.

As a rule, the surgeon has been called to treat these conditions, and therefore they have been studied more from the standpoint of the influence of such operations on pregnancy than of pregnancy on conditions which otherwise might be considered operative.

In this country continuous observation of a woman during pregnancy is almost unknown.

The number of complicated cases, therefore, which have been observed by any one individual has been limited. It is true that in some well-to-do families observation is practiced; but as the importance of this observation is recognized, the occasions for it decrease.

Most obstetrical cases are in charge of general practitioners, and this condition will, undoubtedly, continue. The combination of a skilled obstetrician and surgeon is not a common one, and while the obstetrician may be most skillful in all that pertains to diagnosis of position and in the performance of obstetrical operations, the men in charge of these cases still turn to the surgeon when other operative complications are present.

Surgical interference has also been encouraged by the attitude of obstetricians toward "operative delivery" in cases which may be called, from the surgical standpoint, uncomplicated. This is on the increase, especially in large cities, ${ }^{1}$ and, undoubtedly, tends to encourage surgical intervention in a growing list of obstetrical conditions. The practitioner, who has seen the development of "surgical trusts" under the name of "hospitals," hesitates when he considers what his financial end is to be if he further countenances the fallacious idea that patients can not be successfully treated at home.

On the other hand, the desire for personal consideration and to remain at home, if possible, is still strong among those who have not contracted "the hospital habit."

* Read in the Section on Ohstetrics and Diseases of Women of the American Medical Association, at the Fifty-sixth Annual Session. July, 1905

1. Voorhees: Am. Jour. Ob., January, 1905.
With the large number of competent operators who desire only fair remuneration for services rendered it rests with the general practitioner whether or not he will lose the best part of his practice among the great middle class as he has lost it among what may be considered the opulent poor and the economically inclined opulent.

The care of the pregnant woman is by far our most important duty, and any improvement in treatment or in the care which tends to lessen her dangers during this trying period is of utmost importance.

The value of recognizing deviations from the normal early in the conduct of these cases can not be overestimated; acting with conservative promptness in the presence of dangerous complications will save many lives, both fetal and maternal.

Surgical interference is more important in certain conditions in the pregnant than in the non-pregnant.

It has long been an accepted fact that high maternal temperatures are dangerous to intrauterine life, and that when the temperature rins over $104 \mathrm{~F}$. for a continued period of time, no matter from what cause, it is invariably fatal to the child in utero. ${ }^{2}$

Suppurative conditions with much lower temperature are dangerous, especially if the process is active in close relation to the uterus.

The study by Straviskiadis of twenty-four cases, including pneumonia, typhoid fever, pyemia, etc., in which macroscopic, microscopic and bacteriologic examinations were made, is a distinct addition to our knowledge of this subject. His conclusions are: 1. An acute endometritis which is often hemorrhagic is of frequent occurrence in acute, infectious disease. 2 . This inflammation is caused by the specific bacteria that caused the disease or a complication. 3. Particularly favorable conditions are present during pregnancy and the puerperium for the increase of the bacteria which reach the uterus through the blood current. 4. Abortion or premature labor is frequently due to endometritis of hematogenous origin. ${ }^{\mathbf{3}}$

The intimate relation existing between the appendicular lymphatics and those of the broad ligament is of importance in determining the influence of septic conditions of the appendix on pregnancy; but the hematogenous channel, in view of the fact that there is increasing evidence that sentic emboli may cause disturbances in the gastrointestinal mucous membrane and elsewher seems the most probable route of endometrial infection."

APPENDICITIS.

Appendicitis frequently complicates pregnancy. The condition of obstinate and continued constipation which is so frequent during pregnancy must be looked on as a predisposing cause. Add to this increasing deviation from the usual physiologic condition of the pelvic organs of women between the ages of 15 and, 45 , the mechanical disturbances and congestion resulting from the rapidly growing uterus, and the wonder increases that troubles are not more common. In many cases an absolute diannosis has not been made, because of the mildness of the svmptoms.

In the diagnosis of anpendicitis during pregnancy the usual signs may be obscured. Vomiting is often concurrent with pregnancv. As a rule, the pain is localized at the diaphragmatic attachments, while accelera-

2. Maclhatter: New Yolk Med. Journal, 1901.

3. Monat. F. Geb. und Grn., Rerlin, 1903.

4. Clado: Bend. Soc. de Biol., Paris, 1892, vol. It.

5. Fowler: Brokklyn Med. Jour.. July, 1903. 